\title{
Chemical Analysis of Reinforced Stabilized Soil
}

\author{
Gul Muhammad*, Amanullah Marri and Hafiz Abdus Sami \\ Department of Civil Engineering, NED University of Engineering and Technology, Karachi-75270. Pakistan; \\ gulmohammad@neduet.edu.pk, amanmuri@neduet.edu.pk,engr.hafiz.abdussami@gmail.com
}

\begin{abstract}
Objectives: This study aims at investigating lime and wheat straw as a chemical approach to improve clayey soils as an alternative to the traditional physical process of soil improvement. Methods/Statistical Analysis: A series of tests were conducted on clayey soils mixed with various percentages of lime and wheat straw. The readings were taken on the daily, weekly and monthly basis. The soil and water sample testing was based on pH, TDS, water hardness, Organic Content (OC) and Electrical conductivity (EC). Findings: The test results suggest that there are significant chemical changes resulting due to the addition of lime and/or wheat straw into the water and soil. An increase in pH, TDS and organic contents and a decrease in the electrical conductivity of soil was noticed both in short-term and long-term effects. The results indicate that by knowing chemical process some of the undesirable chemical changes could be seized to only permit the useful chemical changes in a particular process of the addition of soil stabilizing agents. Moreover, it has been noticed that a single soil stabilizing agent may not be sufficient to improve several engineering properties; therefore, combined soil stabilization techniques might be adopted for a wider range of soil improvement where necessary. Application/Improvements: The outcomes of present study would be of potential applications in the ground improvement field. The outcomes provide useful information about the chemical changes involved in process of ground improvement.
\end{abstract}

\section{Keywords: Chemical Analysis, Decomposition, Reinforced Soil, Soil Stabilization}

\section{Introduction}

The reinforcement and stabilization of soil are generally assessed by mechanical processes, for instance; cement, lime or fibre effects into the soil are measured through compressive strength, shear strength, and other mechanical properties. However, there are some chemical and biological changes involved in the process of soil improvement as well. For example, the addition of chemicals such as lime and fibres such as wheat straw into the soil may also be accompanied by chemical and biological changes. The chemical and biological effects in water and soils due to the lime and wheat straw are very vast. For example, the objectives of ${ }^{1}$ were to investigate the response of wheat straw decomposition to increasing nitrogen availability ${ }^{2}$, focused on wheat straw exposed to anaerobic and aerobic decomposition in the soil mass ${ }^{-}$. Investigated the effect of available $\mathrm{C}$ and $\mathrm{N}$ on the rate of wheat straw decomposition. The objective of the study by ${ }^{ \pm}$was to investigate the effects of residue particle size on the decomposition of wheat straw. Carbon and nitrogen transformations during wheat straw and root decomposition were investigated by $\underline{\underline{5}}$ there are several studies conducted only on the decomposition process of wheat straw and the subsequent chemical and biological changes.

Similarly ${ }^{6}$, determined the effects of lime on organic matter content of the soil ${ }^{7-10}$ and others investigated the effect of lime on the $\mathrm{pH}$ of the soil. According to ${ }^{11}$ in expansive soils, the immediate initial strength gains are due to the cation exchange and flocculation of clay particles in the presence of lime. The Electrical Conductivity (EC) of soils varies depending on the amount of moisture held by soil particles, subsequently, the Electrical Conductivity is low, medium and high in sands, silt and clay respectively and therefore, EC correlates strongly to soil particle size and texture $\frac{12,13}{}$. According to ${ }^{\frac{13}{3}}$ the electrical resistivity of soil is going to decrease as well as the water content of the soil is increasing. The EC measurement of soils mainly

${ }^{*}$ Author for correspondence 
depends upon soil chemical properties, salinity, porosity, temperature, CEC, the integrity of the chemical in soil, and depth of topsoillit-17 . Therefore, the significance of chemical reactions that bring about soil stabilization and reinforcement during ground improvement could not be overlooked for most of the civil engineering works. The long-term behaviour of reinforced soils is strongly influenced by the chemical compatibility between construction materials and neighbouring components $\frac{18,19}{}$. Otherwise, in the absence of chemical compatibility in the long term, various chemical reactions may take place (where organic acids high calcium or gypsum contents may adversely interact with the fibre materials). The chemical changes will also be dependent upon the type of soil stabilizing agents because different soil stabilizing agents having different chemical impacts on the soil $\mathrm{pH}$, TDS, Hardness and electrical conductivity of the soil. These chemical properties, are usually investigated while using water for drinking, agriculture or industrial purposes. How much is the contribution to the chemical changes in the ground improvement and how the unnecessary chemical changes are controlled for achieving the targeted goals are of the key interest? The previous studies have not given adequate attention to this aspect. The main reason of the present study was to investigate the contribution of chemical and biological changes in the ground improvement and their role in controlling the ground improvement process. In this study, some chemical and biological parameters of soil which change due to the addition of soil stabilizing agents were investigated. A reverse approach to considering chemical and biological changes as a source of soil stabilization is applied. For this purpose, various percentages of lime and wheat straw were added into the soil, their effects as a function of time were investigated.

\section{Materials}

\subsection{Soil}

The clayey soil was used as a base material; the index properties of the base material were measured and are

Table 2. Index properties of wheat straw

\begin{tabular}{|c|c|c|c|c|}
\hline $\begin{array}{c}\text { Average diameter, } \mathrm{D} \\
(\mathrm{mm})\end{array}$ & Average length, $\mathrm{L}(\mathrm{mm})$ & $\begin{array}{c}\text { Specific gravity } \\
\left(\mathrm{G}_{\mathrm{s}}\right)\end{array}$ & $\begin{array}{c}\text { Water absorption ratio } \\
(\mathrm{WAR})\end{array}$ & $\begin{array}{c}\text { Tensile strength } \\
(\mathrm{MPa})\end{array}$ \\
\hline 3.1 & 18.4 & $0.34-0.38$ & $\begin{array}{c}300 \% \\
\text { (After } 24 \text { hours })\end{array}$ & 10.13 \\
\hline
\end{tabular}

given in Table 1. As per USCS classification, the soil may be classified as low plastic clay.

\subsection{Wheat Straw}

Threshed wheat straws were used as a reinforcement agent, which is commonly available after separating the wheat from the straw using thresher machines. Wheat Straw (WS) is the agricultural by-product. WS is rich in cellulosic fibres, hemicelluloses, proteins, lignin and $\operatorname{ash}^{20}$. The index properties of wheat straw were determined and are summarized in Table 2.

\subsection{Lime}

Powdered lime is used, which is obtained after crushing lumps of limestone. For a selection of lime, it is very important to know its chemical composition. The chemical composition of the lime studied in this manuscript is being presented in Table 3 .

Table 1. Index and physical properties of soil

\begin{tabular}{|l|r|}
\hline Description & \multicolumn{1}{|c|}{ Value } \\
\hline Percentage Passing No. 10 & 99.2 \\
\hline Percentage Passing No. 40 & 98.2 \\
\hline Percentage Passing No. 200 & 96.5 \\
\hline Plasticity Index, (IP) & 7.77 \\
\hline Liquid limit (LL) & 23.85 \\
\hline Plastic limit (PL) & 16.08 \\
\hline Shrinkage limit(SL) & 13.14 \\
\hline Specific Gravity & 2.600 \\
\hline USCS Classification & CL-ML \\
\hline Percentage of sand between No. 4 to No. 200 sieve & $3.45 \%$ \\
\hline Silt size, 0.074 to 0.005 mm & $48.88 \%$ \\
\hline Clay size, smaller than 0.005 mm & $37.98 \%$ \\
\hline Colloids, smaller than 0.001 mm & $9.70 \%$ \\
\hline Maximum dry density (KN/m3 ) & 18.02 \\
\hline Optimum moisture content (\%) \\
\hline
\end{tabular}


Table 3. The chemical composition of lime

\begin{tabular}{|c|c|}
\hline Constituent & Quantity \\
\hline Insoluble in hydrochloric acid & $0.03 \%$ \\
\hline Substitutes not precipitate by $\mathrm{NH} 4.0 x\left({\mathrm{an} \mathrm{SO}_{4}}_{4}\right)$ & 2.5 \\
\hline chloride & $50 \mathrm{mg} / \mathrm{kg}$ \\
\hline $\mathrm{Sulfate}$ & $500 \mathrm{mg} / \mathrm{kg}$ \\
\hline $\mathrm{Cu}$ & $5 \mathrm{mg} / \mathrm{kg}$ \\
\hline $\mathrm{Fe}$ & $500 \mathrm{mg} / \mathrm{kg}$ \\
\hline $\mathrm{Pb}$ & $2 \mathrm{mg} / \mathrm{kg}$ \\
\hline $\mathrm{Zn}$ & $5 \mathrm{mg} / \mathrm{kg}$ \\
\hline $\mathrm{CaCO} 3$ & $3 \%$ \\
\hline
\end{tabular}

\section{Experimental Setups}

\section{1 $\mathrm{pH}$ Meter for Water}

PHep5 is a water $\mathrm{pH}$ tester with a $0.01 \mathrm{pH}$ resolution and an accuracy of $\pm 0.05 \mathrm{pH}$. This accurate $\mathrm{pH}$ tester features 0.01 resolutions with automatic two-point calibration and temperature compensation in a single, portable, pocket device. The testing was conducted as per ASTM D129318. This test method covers the precise measurement of $\mathrm{pH}$ in water utilizing at least two of seven standard reference buffer solutions for instrument standardization. After calibration, the $\mathrm{pH}$ meter is dipped into the water sample taken in a $50 \mathrm{ml}$ beaker until to get a stable reading displayed.

\section{2 $\mathrm{pH}$ Meter for the Soil}

Digital soil $\mathrm{pH}$ meter 4 in 1 Soil Survey instrument. The instrument can test moisture of soil, $\mathrm{pH}$ value and temperature and environment sunlight intensity using a probe with the length of $200 \mathrm{~mm}$. The unit can easily display with oversize LCD. The testing was conducted as per ASTM D4972 - 13. The test method covers the precise measurement of $\mathrm{pH}$ value in soil within the range of 3.5 to 9.0. The probe was pushed vertically into the soil for $\mathrm{pH}$ measurement. The reading displayed on screen was recorded as $\mathrm{pH}$ of the soil.

\subsection{Muffle Furnace for Organic Content Determination}

Thermolyne-Type-1300-Furnace with chamber size 4" wide, 3.75" height and 4.5" diameter and built-in control working temperature of $1900^{\circ} \mathrm{F}$ was used. The testing was conducted as per ASTM D2974-14. For the determination of the effect of decomposition of wheat straw on the Organic Content (OC) of soil, $100 \mathrm{~g}$ of wheat straw was added into 2 litres of water and a workable paste of soil was prepared. Samples from the prepared paste stored in an airtight container were taken at various time intervals to measure the organic content. For Organic Content determination, the oven dried weight was taken first and then kept in the furnace by gradually raising the temperature to $440 \pm 40^{\circ} \mathrm{C}$ for $24 \mathrm{~h}$. the sample was then taken out from the furnace and burned weight was measured. The organic content was taken as (oven dried weight-burnt weight)/oven dried weight.

\subsection{TDS Meter for Water}

TDS-EZ water quality tester device was used. The device is Factory Calibrated with a $342 \mathrm{ppm} \mathrm{NaCl}$ solution and designed to stay consistent having Range: 0-9990 ppm $(\mathrm{mg} / \mathrm{L})$. The testing was conducted as per ASTM D590710. $100 \mathrm{~g}$ wheat straw submerged in 2 litres of water and the TDS values of the mixture were taken on daily, weekly and monthly bases. The TDS meter was dipped in the solution and the reading was then taken after fully stabilization (taken less than 30 seconds).

\subsection{Titration Test for Water Hardness}

HI 3812 Hardness Test Kit was used. The hardness level was measured as $\mathrm{mg} / \mathrm{L}$ (ppm) $\mathrm{CaCO}_{3}$ by an EDTA (ethylene-diamine-tetra-acetic acid) titration. The low range is from 0.0 to $30.0 \mathrm{mg} / \mathrm{l}(\mathrm{ppm}) \mathrm{CaCO}_{3}$ and the higher range is from 0 to $300 \mathrm{mg} / \mathrm{L}(\mathrm{ppm}) \mathrm{CaCO}_{3}$. The testing was conducted as per ASTM D511-14. Test Method A-Complex Metric Titration is adopted for determination of hardness of water. The complete procedure usually comes with the catalogue.

\subsection{Electrical Conductivity Test of Soil}

Victor VC $60 \mathrm{~B}^{+}$insulation tester device modified with electrode plates of $50 \mathrm{~mm}$ diameter and surcharge weight of $1 \mathrm{~kg}$ was used. The modifications were indigenously made for the determination of electrical conductivity of soil samples. The testing was conducted as per ASTM G187-12a. Soil specimen of $50 \mathrm{~mm}$ diameter and $20 \mathrm{~mm}$ thickness was placed between the electrodes connected with the megger device. A surcharge weight of $1 \mathrm{~kg}$ was 
applied for proper seating. Working voltage of $250 \mathrm{~V}, 500$ $\mathrm{V}, 1000 \mathrm{~V}, \mathrm{AC}-750 \mathrm{~V}$ was selected appropriately to get the electrical resistance value in mega ohm $(\mathrm{M} \Omega)$. The electrical resistance value was taken after stabilization (usually taking less than two minutes).

\section{Results and Discussion}

\subsection{Decomposition of Wheat Straw}

Wheat straws were placed in water and soil-water mixture for decomposition in airtight and open containers. The change in colour and odour level was observed. By the passage of time colour darkness and increase the odour level was noticed during visual observations and smelling tests respectively. The darkness in colour and increase in odour level, in turn, suggests the decomposition of wheat straw which could be due to some chemical and biological changes. Biodegradation and growth of fungal and bacteria could be one of the reasons for the change in colour and of pungent smell. From a biological perspective, this may be termed as decomposition. The other reason according to ${ }^{21}$ could be the carbon dioxide emissions and transformation of soil carbon and nitrogen which occurs during wheat straw decomposition. According to $\underline{22}$ the rate of decomposition of straw is dependent on the rapid colonization by fungal species with the necessary enzyme capabilities to break down constituent compounds. The rate of decomposition and odour level also depends upon aeration which is noticed by the comparison of the samples kept in airtight and open containers. The samples kept in airtight containers indicates a higher rate of decomposition and odour generation level; similar results were reported by $\underline{23}$ as well.

\subsection{Wheat Straw Decomposition Effects on pH of Water and Soil}

A known amount of wheat straw was mixed in fully saturated soil and water for the determination of its effects on the $\mathrm{pH}$ value. The results of $\mathrm{pH}$ for water and soil were taken on daily, weekly and monthly basis. The summarized variation of $\mathrm{pH}$ results for water and soil are shown in Figures 1 and 2. The $\mathrm{pH}$ of the soil gradually increased from 5.0 to 6.6 and the $\mathrm{pH}$ of water gradually increased from 7.0 to 8.6 in the duration of six (06) months. Similar trends of increase in $\mathrm{pH}$ value were also reported in the previous studies as well $\frac{23-26}{2}$. The increase in $\mathrm{pH}$ is generally thought to be the result of volatilization and microbial decomposition of the organic acids and subsequent release of ammonia through mineralization of organic nitrogen sources (which are basic in nature and results in neutralization of acidic properties of water and soil); subsequently resulting to an increase in the $\mathrm{pH}$ of water and soil $\frac{25,26}{}$.

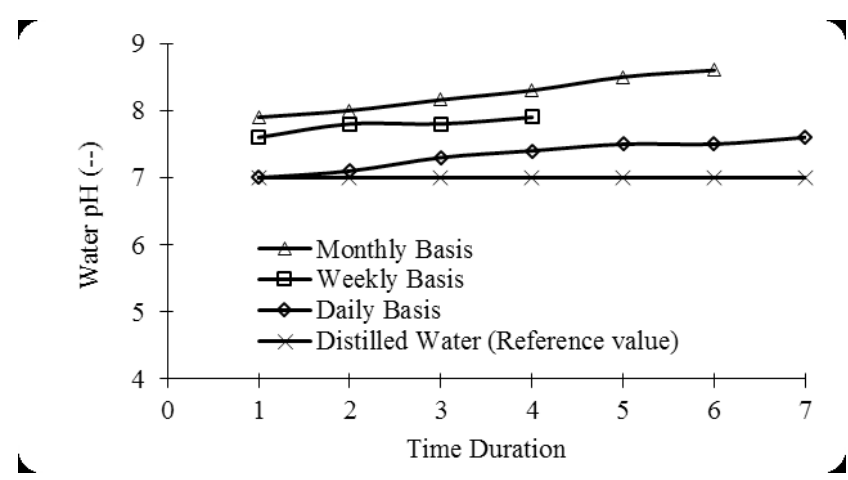

Figure 1. Effect of wheat straw on $\mathrm{pH}$ value of water with time duration.

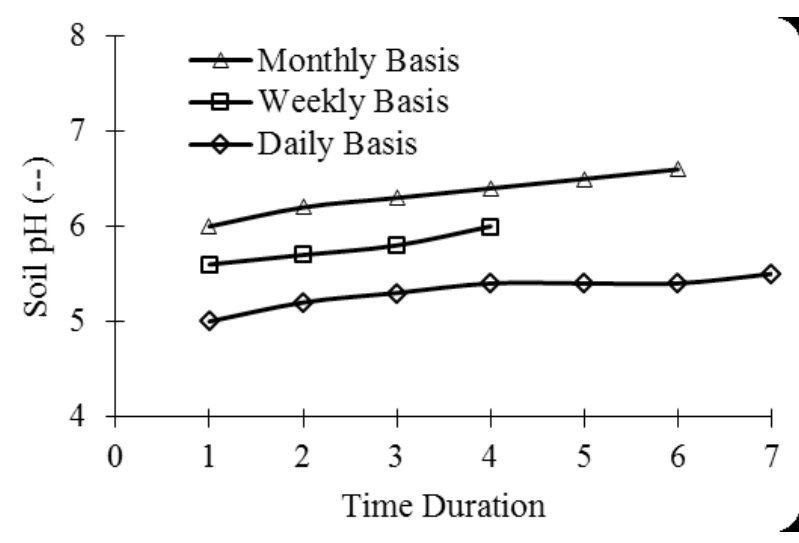

Figure 2. Effect of wheat straw on $\mathrm{pH}$ value of soil with time duration.

\subsection{Effect of WS Decomposition on the TDS Value}

Wheat straws were added to water and allowed for soaking and decomposition. The TDS value of water as a function of time was taken on daily, weekly and monthly basis. The TDS variation with respect to time is shown in Figure 3. From the figure, it can be seen that there is a gradual increase in the TDS value. The increase in TDS might be due to the decomposition and fermentation process as decomposition results in the mineralization of organic nitrogen sources $\frac{25,26}{}$. Previous studies by ${ }^{27}$ also reported an increase in the TDS value. 


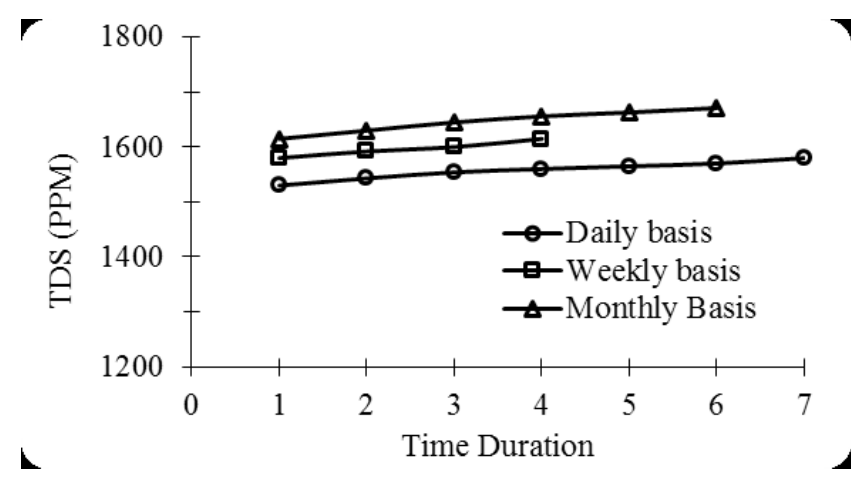

Figure 3. Effect of wheat straw on TDS value of water with time duration.

\subsection{Effect of WS Decomposition on the Organic Matter Content of the Soil}

The variation of organic content as a function of time is shown in Figure 4. The results indicate that there is a gradual increase in the organic content of the soil as a function of time; for example, the organic content of a soil added with wheat straw resulted to an increase of $5.7 \%$ to $8.29 \%$ in organic content for a period of six (06) months. Similar trends of increase in organic content value were also reported in the previous studies as well ${ }^{28-30}$. The increase in the organic content might be due to the decomposition of wheat straw; because, after decomposition the organic matters becoming the part of soil; as fundamentally, soil solids consist of minerals and organic compounds. From a mechanical behaviour perspective, increase in organic content may have adverse effects on the shear and compressibility characteristics of soil; as organic soils have the low shear strength and high compressibility ${ }^{\underline{31}}$.

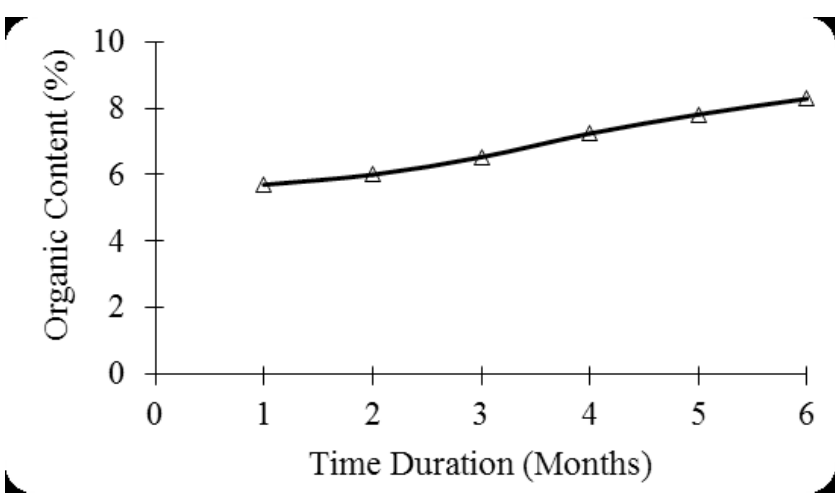

Figure 4. Effect of wheat straw on organic content of soil with time duration.

\subsection{Effect of Lime on the $\mathrm{pH}$ of the Water}

Various percentages of lime were added to tap water and $\mathrm{pH}$ values were observed. The results were plotted as shown in Figure 5. The results show that the rate of increase in $\mathrm{pH}$ is high up to $2 \%$ lime content; however, further increase in the lime resulting to no significant increase in the $\mathrm{pH}$ value; i.e. maximum $\mathrm{pH}$ saturation of water is being attended at around $2 \%$ lime content. Increase in the $\mathrm{pH}$ value due to the addition of lime content was also reported by $\frac{32-35}{2}$. From $\mathrm{pH}$ scale lime is basic in nature; therefore, resulting in the neutralization of the acidic effects that might be the reason for an increase in the $\mathrm{pH}$ of water. From previous literature review and present investigations, it can be seen that minimum $2 \%$ lime is required for stable water. According to ${ }^{\frac{36}{6}}$ "Stable" water has tendency neither precipitate nor dissolves calcium carbonate $\left(\mathrm{CaCO}_{3}\right)$ (i.e., saturated) with respect to calcium carbonate.

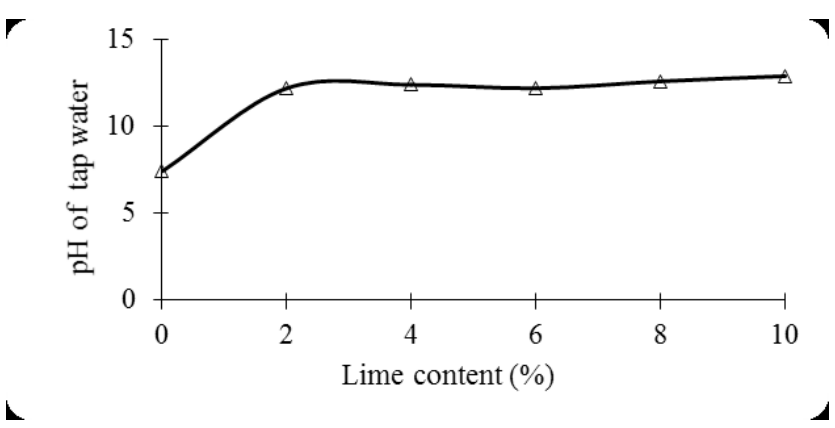

Figure 5. Effect of lime content on $\mathrm{pH}$ of tap water.

\subsection{Effect of Lime and WS on Water Hardness}

Effect of lime and WS were investigated on the water hardness, as there is little information available in the literature regarding the effect of fibres and lime on the water hardness. For this purpose, wheat straw was decomposed in water and hardness test was conducted on it; however, using titration process the hardness could not be determined, as there were no colour changes noticed during titration process. Therefore, alternative methods such as soap test kit and hard water tests were used where the titration process not worked.

Addition of lime in water resulted to decrease in the water hardness. The hardness of $100 \mathrm{mg} / \mathrm{l}$ decreased to $25 \mathrm{mg} / \mathrm{l}$ due to the addition of $2 \%$ lime in water approxi- 
mately. The decrease in the water hardness might be due to the precipitation of soluble carbonates and bicarbonates to non-soluble ones. Historically lime softening has been an effective technique to remove hardness (calcium and magnesium) ions by precipitation, nevertheless, according to ${ }^{37}$ the total hardness stays stable between $0 \%$ and $20 \%$ of lime addition and begins to decrease significantly with the increase of lime dose.

\subsection{Wheat Straw and Lime Effect on Electrical Conductivity}

Various percentages of lime and wheat straw were added to the soil and moulds of $50 \mathrm{~mm}$ diameter and $20 \mathrm{~mm}$ thickness were prepared. After curing and subsequent oven drying the samples were tested for electrical conductivity. For this purpose, an indigenously developed experimental setup was used as discussed in the experimental setups. The graphical representation of the test results is shown in Figure 6 and observed that the effect of lime and wheat straw on the electrical conductivity and electrical resistivity. The results suggest that there is a gradual decrease in the electrical conductivity of soil due to the addition of lime and/or wheat straw. The rate of decrease is high up to $6 \%$ lime and wheat straw contents each; however, thereafter, the rate of decrease is comparatively low. For instance, the electrical conductivity of clayey soils decreased from $1.4 \mathrm{mS}$ to $0.38 \mathrm{mS}$ and from $1.4 \mathrm{mS}$ to $0.135 \mathrm{mS}$ for lime and wheat straw contents respectively. Decrease in the electrical conductivity of soil due to the addition of lime was also reported by $\frac{38,39}{}$. The decrease in electrical conductivity is associated with a simultaneous increase in strength and also the number of dissolved minerals hence there is a possibility of developing a correlation between strength and electrical conductivity.

\section{Conclusions}

From the results the following conclusions were drawn:

- There is a significant effect of lime and wheat straw (used as soil stabilizing and reinforcing agents respectively) on the chemical and biological properties of water and soil. This is evident from an increase in odour level and colour darkness due to decomposition of wheat straw in water and soil, increase in $\mathrm{pH}$ due to lime and wheat straw, increase in the TDS of water due to wheat straw



Figure 6. Wheat straw and lime effects on electrical conductivity and electrical resistivity characteristics.

decomposition, decrease in the water hardness due to lime, an increase in the organic matter content due to addition of wheat straw into soil.

- As soil stabilization is a physical, chemical, biological or combined method of changing a natural soil to meet an engineering purpose, hence apart from physical changes the chemical and biological changes are supposed to be the major factors controlling the stabilization mechanism. Therefore, the stabilization process may also be controlled through chemical and biological changes.

- A single soil stabilizing agent may not be sufficient to improve several engineering properties; because stabilization does not necessarily improve all engineering properties for better as is seen in present studies. Therefore, combined soil stabilization techniques might be adopted for a wider range of soil improvement where necessary.

\section{Acknowledgement}

The authors express gratitude to Civil Engineering Department, NED University of Engineering and Technology, Karachi, for the support and assistance to conduct this research.

\section{References}

1. Henriksen T, Breland T. Nitrogen availability effects on carbon mineralization, fungal and bacterial growth and enzyme activities during decomposition of wheat straw in soil. Soil Biology and Biochemistry. 1999; 31(8):1121-34. https://doi.org/10.1016/S0038-0717(99)00030-9 
2. Lynch J. Phytotoxicity of acetic acid produced in the anaerobic decomposition of wheat straw. Journal of Applied Bacteriology. 1977; 42(1):81-7. PMid: 853029. https://doi.org/10.1111/j.1365-2672.1977.tb00672.x

3. Reinertsen SA, Elliott L, Cochran V, Campbell G. Role of available carbon and nitrogen in determining the rate of wheat straw decomposition. Soil Biology and Biochemistry. 1984; 16(5):459-64. https://doi. org/10.1016/0038-0717(84)90052-X

4. Angers DA, Recous S. Decomposition of wheat straw and rye residues as affected by particle size. Plant andS. 1997; 189(2):197-203. https://doi.org/10.1023/A:1004207219678

5. Jawson M, Elliott L. Carbon and nitrogen transformations during wheat straw and root decomposition. Soil Biology and Biochemistry. 1986; 18(1):15-22. https://doi.org/10.1016/0038-0717(86)90097-0

6. Haynes R, Naidu R. Influence of lime, fertilizer and manure applications on soil organic matter content and soil physical conditions: A review. Nutrient Cycling in Agro-ecosystems. 1998; 51(2):123-37. https://doi. org/10.1023/A:1009738307837

7. McLean E. Soil pH and lime requirement. Methods of Soil Analysis. Part 2. Chemical and Microbiological Properties; 1982. p. 199-224.

8. Barrow N. Modeling the effects of $\mathrm{pH}$ on phosphate sorption by soils. Journal of Soil Science. 1984; 35(2):283-97. https://doi.org/10.1111/j.1365-2389.1984.tb00283.x

9. Mathew PK, Rao SN. Effect of lime on cation exchange capacity of marine clay. Journal of Geotechnical and Geo Environmental Engineering. 1997; 123(2):183-5. https:// doi.org/10.1061/(ASCE)1090-0241(1997)123:2(183)

10. Haynes R. Effects of liming on phosphate availability in acid soils. Plant and Soil. 1982; 68(3):289-308. https://doi. org/10.1007/BF02197935

11. Lucian C. Stress-Strain behaviours of two stage limecement treated expansive soils. International Journal of Environmental, Chemical, Ecological, Geological and Geophysical Engineering. 2015; 9(12):1339-43.

12. Grisso RD, Alley MM, Holshouser DL, Thomason WE. Precision farming tools: Soil Electrical Conductivity. Virginia Coorperative Extension; 2005. p. 1-6. PMid: 15865329.

13. Chik Z, Islam T. Study of chemical effects on soil compaction characterizations through electrical conductivity. International Journal of Electrochemical Science. 2011; 6:6733-40

14. Pringle JK, Jervis JR. Electrical resistivity survey to search for a recent clandestine burial of a homicide victim, UK. Forensic ScienceInternational.2010;202(1-3):e1-e7.PMid:20471188. https://doi.org/10.1016/j.forsciint.2010.04.023
15. Saltas V, Vallianatos F, Soupios P, Makris J, Triantis D. Dielectric and conductivity measurements as proxy method to monitor contamination in sandstone. Journal of Hazardous Materials. 2007; 142(1-2):520-5. PMid: 17010511. https://doi.org/10.1016/j.jhazmat.2006.08.051

16. Wick LY, Shi L, Harms H. Electro-bioremediation of hydrophobic organic soil-contaminants: A review of fundamental interactions. Electrochimica Acta. 2007; 52(10):3441-8. https://doi.org/10.1016/j.electacta.2006.03.117

17. Morrow F, Ingham M, McConchie J. Monitoring of tidal influences on the saline interface using resistivity traversing and cross-borehole resistivity tomography. Journal of Hydrology. 2010; 389(1-2):69-77. https://doi.org/10.1016/j. jhydrol.2010.05.022

18. Terzaghi K, Peck RB, Mesri G. Soil mechanics in engineering practice. 3rd ed. John Wiley and Sons; 1996. p. 1-534.

19. Ingold TS, Europe SPoSRi, Group T, Society IG. The practice of soil reinforcing in Europe. Proceedings of the Symposium the Practice of Soil Reinforcing in Europe held at the Institution of Civil Engineers; Telford. 1995.

20. Khan TS, Mubeen U. Wheat straw: A pragmatic overview. Current Research Journal of Biological Sciences. 2012; 4:673-5.

21. Curtin D, Selles F, Wang H, Biederbeck V, Campbell C. Carbon dioxide emissions and transformation of soil carbon and nitrogen during wheat straw decomposition. Soil Science Society of America Journal. 1998; 62(4):1035-41. https://doi.org/10.2136/sssaj1998.03615995006200040026x

22. Moody SA, Piearce TG, Dighton J. Fate of some fungal spores associated with wheat straw decomposition on passage through the guts of Lumbricusterrestris and Aporrectodea longa. Soil Biology and Biochemistry. 1996; 28(4-5):533-7. https://doi.org/10.1016/0038-0717(95)00172-7

23. Pan I, Sen S. Microbial and physico-chemical analysis of composting process of wheat straw. NISCAIR-CSIR, India. 2013; 123(1):120-8.

24. Wani SP, Shinde P. Changes in temperature and $\mathrm{pH}$ of wheat straw during its decomposition. Indian Journal of Microbiology. 1975; 15(2):94-5.

25. Corbeels M, Hofman G, Van Cleemput O. Nitrogen cycling associated with the decomposition of sunflower stalks and wheat straw in a Vertisol. Plant Soil. 2000; 218(1-2):71-82. https://doi.org/10.1023/A:1014904505716

26. McKinley VL, Vestal JR. Physical and chemical correlates of microbial activity and biomass in composting municipal sewage sludge. Applied and Environmental Microbiology. 1985; 50(6):1395-403. PMid: 16346940 PMCid: PMC238770.

27. Okowa IP, Kigigha LT, Izah SC. Variation in physicochemical water quality parameters during fermentation of 
maize for Ogi production. Biotechnology Research. 2016; 2(3):125-31.

28. Mouhamad R, Atiyah A, Mohammad R, Iqbal M. Decomposition of organic matter under different soil textures. Current Science. 2015; 1(1):22-5.

29. Zhang P, Wei T, Jia Z, Han Q, Ren X, Li Y. Effects of straw incorporation on soil organic matter and soil water-stable aggregates content in semiarid regions of Northwest China. PLoS One. 2014; 9(3):e92839. PMid: 24663096 PMCid: PMC3963976. https://doi.org/10.1371/journal. pone.0092839

30. Chandra P, Bollen W. Soil organic matter, effect of wheat straw, nitrogenous fertilizers, and carbon-to-nitrogen ratio on organic decomposition in a subhumid soil. Journal of Agricultural and Food Chemistry. 1960; 8(1):19-24.

31. Edil TB. Construction over peats and organic soils. Conference on Recent Advances in Soft Soil Engineering; Huat and Bahia, Sarawak. 1997. p. 85-108.

32. Muhmed A, Wanatowski D. Effect of lime stabilisation on the strength and microstructure of clay. IOSR Journal of Mechanical and Civil Engineering (IOSR-JMCE). 2013; 6(3):87-94.

33. Helfrich LA, Neves RJ, Parkhurst JA. Liming acidified lakes and ponds. Virginia Cooperative Extension; 2001. PMCid: PMC86888.
34. Al-Swaidani A, Hammoud I, Meziab A. Effect of adding natural pozzolana on geotechnical properties of lime-stabilized clayey soil. Journal of Rock Mechanics and Geotechnical Engineering. 2016; 8(5):714-25. https://doi. org/10.1016/j.jrmge.2016.04.002

35. Al-Mukhtar M, Lasledj A, Alcover J-F. Behavior and mineralogy changes in lime-treated expansive soil at $20 \mathrm{C}$. Applied Clay Science. 2010; 50(2):191-8. https://doi.org/10.1016/j. clay.2010.07.023

36. Morgan JM, Walski TM, Corey MW. Estimating chemical doses for water stabilization. Journal of Environmental Engineering. 1987; 113(6):1202-18.https://doi.org/10.1061/ (ASCE)0733-9372(1987)113:6(1202)

37. Seyrig G, Shan W. Chemical precipitation: Water softening. College of Engineering, Michigan State University; 2007. p. $1-20$.

38. Boardman D, Glendinning S, Rogers C, Holt C. In situ monitoring of lime-stabilized road subgrade. Transportation Research Record: Journal of the Transportation Research Board. 2001; 1757:3-13.

39. Lestari Y, Maas A, Purwanto BH, Utami SNH. The influence of lime and nitrogen fertilizer on soil acidity, growth and nitrogen uptake of corn in total reclaimed potential acid sulphate soil. Journal of Agricultural Science. 2016; 8(12):197-205. https://doi.org/10.5539/jas.v8n12p197 